\title{
The Role of Marketing Resources and Marketing Dynamic Capabilities in Improving Business Performance of Insurance Firms in Iran
}

Bagher Asgarnezhad Nouri

Department of Management and Economy, Faculty of Literature and Humanities, University of Mohaghegh Ardabili, Ardabil, Iran

Mohammad Ghaffari

Department of Management, Faculty of Pardis Farabi, University of Tehran, Qom, Iran

Mohammad Jafar Ram Pahlavanloo

Department of Management, Faculty of Pardis Farabi, University of Tehran, Qom, Iran, and

Mehdi Danesh

Department of Management and Economy, Faculty of Literature and Humanities, University of Mohaghegh Ardabili, Ardabil, Iran

\begin{abstract}
Purpose - This study aims to investigate the effect of marketing resources and marketing dynamic capabilities on the business performance of insurance companies.

Design/methodology/approach - The population consists of all employees of the insurance firms in Ardabil and among them a sample of 177 people was selected using non-random convenience method. A standard questionnaire was used to measure variables. The hypotheses were analyzed using structural equation modeling method with use of SmartPLS software.

Findings - The results show that marketing resources have a positive impact on marketing dynamic capabilities. Also, marketing dynamic capabilities have a positive impact on customer performance and market performance. Finally, the positive impact of market performance and customer performance on financial performance was also confirmed.

Originality/value - There is lack of research explaining the role of marketing resources and marketing dynamic capabilities in improving business performance in service industries, especially in important insurance industry. This study attempts to reduce this gap in the literature, as its main goal is to assess the impact of marketing dynamic capabilities in improving business performance of insurance firms.

Keywords - Marketing Resources, Marketing Dynamic Capabilities, Marketing Performance, Insurance Firms.

Paper type - Research paper.

\section{Introduction}

Now a days, competitive markets force companies to adopt competitive strategies (Slater and Narver, 1994). Improvement in the business environments and competitiveness in the 21 th century markets are two main factors that make difficulties for companies survive. This is why companies attempt to increase their market share through improving their intangible capitals and thereby improve their organizational performance in business environments (Krasanikov and Jayachandran, 2008). In this regard, marketing, as one of the main areas, plays an important role in organizational performance (Srivastava and Reibstein, 2005; Kozlenkova et al., 2014; Ketchen and Hult, 2011). According to the marketing literature review, there are two main theories for conceptualizing marketing including Resource-based View and Dynamic Competencies Theory.
\end{abstract}

The Role of Marketing Resources and Marketing Dynamic Capabilities

\section{8}

Received: 04.11.2018 Revised: 29.01 .2020 13.02.2020 31.05 .2020

Accepted: 17.08 .2020 
GBR

Vol. 16

Resource-based View implies uniqueness of resources and differences in organizational capabilities to create value. This view, finally, leads to differences in organizational performance (Mahoney and Pandian, 1992). In this view, resource is a tangible or intangible, physical, human, mental, and even relational character that can be used by organizations for offering high-value products in target markets (Hunt, 2000). It is supposed in this study that marketing resources include market orientation and managerial capabilities. Generally, managerial capabilities, as a personal characteristic, has considerable role in both individual and organizational successful performance. It includes knowledge, skills, abilities, and even other characteristics such as values, motivation, innovation, and self-control (Hooley et al., 2005). Market orientation includes a set of beliefs and opinions that focus on customers for achieving organizational long-term profitability (Desphande et al., 1989). On the other hand, marketing theorists have new achievements in weaknesses of resource-based view that has been known as marketing dynamic capabilities. It is supposed in this view that marketing is a dynamic concept and it is marketing tactical capabilities by which resources can be achieved and allocated in organizations that lead to differences in organizational performances (Newbert, 2007). Generally, there are three types of marketing tactical capabilities including Marketing Specialized Capabilities, Marketing Cross-Functional Capabilities, and Marketing Dynamic Capabilities (Morgan, 2012; Varadarajan, 2012). In this study, marketing dynamic capabilities have been focused. In this regard, marketing dynamic capabilities are defined as the capacity of marketing knowledge attraction and management (Cacciolatti and Lee, 2016). Marketing dynamic capabilities refer to the ability of marketing unit to participate in market-based learning and applying its results in recognizing company resources and promoting its capabilities so that reflect dynamic environment of companies' market (Vorhies et al., 2009). Marketing dynamic capabilities empower organizations in market sensing, market learning, and applying the learnings. As a result, organizations will be able to deliver goods and services according to customers' needs better than competitors (Krasnikov and Jayachandran, 2008).

The present study aims to investigate the effect of marketing resources and marketing dynamic capabilities on the performance of insurance companies. This study can be helpful from both scientific and practical views. The academics interest in marketing performance measurement is based on the proposition that more marketing accountability results in higher levels of organizational performance (O'Sullivan et al., 2009). On the other hand, lack of marketing managers' accountability and increased attention to this issue have damaged marketing reliability and threaten marketing identity (Morgan, 2012). Accordingly, the role of marketing resources and dynamic marketing capabilities in improving the business performance of insurance companies in Iran has been somewhat neglected.

Today, the services sector plays a key role in the country's economy, in such a way that more than seventy-five percent of the gross national product (GNP) of developed countries is related to their services sector and this rate is constantly increasing. Various changes in the environment, such as changes in customer expectations, threaten existing services and create new opportunities for new services. In order to avoid these threats as well as take advantage of the fleeting opportunities ahead, companies should use the marketing resources and marketing dynamic capabilities. The insurance industry, as one of the most important service industries that plays an important role in the economy of countries and has a significant share of gross domestic product, is no exception to this rule. Since nowadays, the firms providing insurance services operate in dynamic and competitive environment and they all strive to gain more market share by increasing customer satisfaction and loyalty, it is necessary for them to provide better and newer services or improve their quality. In Iran, too, given the significant growth of the insurance industry during the last decade and expansion of insurance companies (public and private) and increasing competition to attract and retain customers, it seems that there is a necessity to pay attention to marketing capabilities and offer high quality services. Therefore, considering the intensity of competition between insurance service companies, conducting a study to examine marketing dynamic capabilities and importance of marketing resources in these companies as well as understanding how they affect business performance, can be a great help to 
companies to improve and develop their services and processes and it can be a step towards developing marketing activities in companies.

\section{Literature review}

2.1 Marketing resources

Generally, resource is a tangible or intangible, physical or human, mental and relational character that can be used by organizations in delivering goods and services according to target markets (Hunt, 2000). Specially, intangible (market-based) resources, like to market orientation, reputation, and innovation, are considered as the most effective resources in creating sustainable competitive advantage. Marketing resources help to value creation in markets (Hooley et al., 2005). It is supposed in this study that marketing resources consist of two main components including market orientation and managerial capabilities.

Market orientation: currently, companies need to achieve information about present and potential customers and disseminate them in organizational departments so exactly that they can react to the market changes. The departments also have to monitor market conditions and understand customers' needs and competitors' strategies perfectly. Such information will be helpful in promoting organizational learning and innovations. According to the marketing dynamic capabilities, marketing processes of a company, which are used for responding environmental changes, are combined based on the conditions of target market and are influenced by market orientation (Wang et al., 2013).

Managerial capabilities: generally, marketing capabilities refer to this fact that managers direct their work teams through models or role modeling; facilitate members' participation in decision-making; show cheerleader behaviors, show members attention, and inform them about organizational policies and team adaptation with future goals forganization. Leadership capabilities are important part of dynamic work climate and it is claimed the climate is an important prerequisite of organizational learning and knowledge creation (Menguc et al., 2013).

\subsection{Dynamic marketing capabilities}

Marketing capability can be defined as a complex process of organizational resources and market knowledge combination to create added-value (Tan and Sousa, 2015). According to Morgan (2012), and Varadarajan (2012), tactical marketing capabilities include marketing specialized capabilities, marketing cross-functional capabilities, and marketing dynamic capabilities. Dynamic capability refers to organizational ability in participating in marketbased learning and applying its knowledge in recombining organizational resources and promoting organizational capabilities so that reflect dynamic market conditions. Combination of dynamic capabilities theory and information of strategic marketing literature indicates that dynamic marketing capabilities consists of three parts: market sensing, market learning, and customer-linking capabilities (Morgan, 2012).

\subsubsection{Market sensing capability}

Refers to the capability of collecting new market information to recognize opportunities and threats. Market sensing capability is a process by which organizations acquire and interpret necessary information and then act based on them. Indeed, market sensing capability is a process by which individuals make their business meaningful (Perez-Cabanero et al., 2012). Market-sensing capability reflects a firm's systematic, thoughtful, and anticipatory ability to "learn about customers, competitors, and channel members in order to continuously sense and act on events and trends in present and prospective markets" (Day, 1994). This capability generates superior market knowledge, which is posited to be critical for any dynamic capability.

The literature suggests numerous reasons to expect that market sensing capabilities may be linked with firms' financial and market performances. Superior market-sensing capabilities allow a firm to identify underserved segments and those where its rivals' offerings may not be fulfilling customer and channel requirements (Slater and Narver, 2000). These underserved and/or unsatisfied segments provide good targets for the firm's efforts to grow revenue by 
attracting new customers. Firms with strong market-sensing capabilities are also better able to identify the least price sensitive customers and prospects, which enables them to charge higher prices. These capabilities should also provide new insights into how a firm's product and service offerings may provide the greatest non-price value to customers and channel members (Slater and Narver, 2000). Meanwhile, from a margin growth rate perspective, we expect strong market-sensing capabilities to facilitate CRM by continuously enabling firms to better distinguish high profit potential prospects from others, leading to increasingly higher margin new customers being attracted to the firm (Cao and Gruca, 2005). They may also facilitate CRM by providing superior knowledge about competitors, especially with respect to their value offerings and prices, which should enable firms with strong CRM capabilities to continuously identify the highest price points at which attractive existing customers can be retained (e.g., Boulding et al., 2005). Market sensing capabilities also provide competitor and channel insights that enable managers to more accurately gauge customers' value-offering referents and therefore make better decisions concerning how to allocate resources in serving attractive prospects and existing customers.

\subsubsection{Market learning capability}

This reflects a firm's ability to actively and purposefully learn about customers, competitors, channel members, and the broader business environment in ways that not only allow a deep understanding of the current marketplace conditions but also permit future marketplace changes to be predicted (Day, 2011). This is a step beyond previous conceptualizations of "market sensing" which drew on "sense-and respond" models. Rather, in increasingly complex and dynamic markets, firms need to more actively probe and experiment in order to be able to anticipate broader marketplace changes rather than more passively monitor the market and respond accordingly when changes occur (e.g., Day 2011). This capability therefore allows the firm to generate superior market knowledge, which is posited to be a pre-condition for any dynamic capability (Eisenhardt and Martin 2000; Grant 1996b). Since learning is the process of acquiring, processing, retrieving, and storing new knowledge (Fiol and Lyles 1985; Helleloid and Simonin 1992), this capability draws together and coordinates a number of resources and lower-level capabilities including: the firm's leadership team (e.g., Day 2011); formal market research activities such as market surveys, experiments, test marketing, customer database analyses, etc. (e.g., Moller and Anttila 1987); informal market scanning and intelligence generation (e.g., Kohli and Jaworski 1990); and research and intelligence exchange and interpretation (e.g., Slater and Narver 1995). A learning capability is defined as the capacity to acquire, assimilate, and exploit new knowledge that enables informed decision making. Learning is argued as being a very important process, which through experimentation and repetitions leads to better and swifter problem resolution (Teece et al., 1997).

\subsubsection{Customer-linking capability}

First and foremost, among the market-based resources of any organization will be the outsidein or customer-linking capabilities identified by Day (1994). These include the ability to identify customer wants and requirements together with the capabilities to create and build appropriate relationships with those customers. Customer-linking capabilities exhibit many of the characteristics of sustainable competitive advantage creation noted above. They take time to develop, rely on the complex interplay of supporting resources, are based primarily on tacit knowledge and interpersonal skills, and are inherently difficult for competitors to imitate. Potentially, then, as Day (1994) has argued, these capabilities are among the most valuable of any organization.

Well-developed customer-linking capabilities, such as the ability to identify customer requirements, the ability to create, maintain, and enhance customer relationships, together with marketing innovation capabilities such as the ability to launch successful new products and services, are all likely to lead to higher levels of customer satisfaction and subsequently loyalty (Dick and Basu, 1994). In addition, it might be expected that strong reputational assets, such as well-known brands and market credibility, also contribute to customer satisfaction and loyalty through positive associations with well-known and leading brands 
(Doyle, 2000). Less experienced customers in particular are likely to be attracted to the reassurance offered by purchasing and remaining loyal to leading brands (Aaker, 1991). Superior customer-linking capabilities are likely to directly influence sales levels through ensuring customer expectations and requirements are directly met (Day, 1994).

\subsection{Business performance}

Performance is one of the most-discussed topics in management studies and one of the most important success criteria measurement in businesses. However, there is not any comprehensive agreement about criteria and dimensions of performance. All in all, performance criteria can be divided into two parts: financial and nonfinancial criteria (AnningDorson, 2017). Financial performance criteria refer to factors that are measured based on the real data such as return on assets, return on equity, return on investment, earnings per share, stock returns, and etc. Although, financial criteria are necessary to performance evaluation, but conceptual performance is more complex and comprehensive than common financial ratios. Increased discussions on performance measurement tell us that it is necessary to adjust traditional economic evaluation with nonfinancial performance evaluation.

Marketing researchers and managers focus on three different aspects of business performance: customer performance, market performance, and financial performance (Narver and Slater, 1990). In the present study, the above-mentioned categorization has been used for measuring business performance of insurance companies. Customer performance can be examined based on the marketing assets. On the other hand, marketing assets are customerbased measurement criteria that can improve companies' long-term value. In addition, market performance is another criterion of business performance measurement. If other conditions persist, improvement in market performance results in change in the following criteria: increase in sales, improvement in customer satisfaction and conative loyalty, decrease in the customer sensitivity to prices, and increase in market share. From financial performance view, organizational success can be measured based on the accounting criteria such as cash flows, profitability, and other financial criteria like to investor value (Karabulut, 2015; Agostini and Nosella, 2016).

\subsection{Hypotheses development}

Market orientation refers to organizational culture that focuses on acquiring, disseminating, and responding to customer and competitor information (Kohli and Jaworski, 1990). Market orientation manifests the organization's marketing philosophy and highlights the necessary behaviors of organizational managers and employees for the creation of values for customers. It also entails the implementation of customer-focused marketing concept through which organizations achieve competitive advantage (Pelham ,1997). Researchers have attributed marketing dynamic capabilities as one of the major success factors of businesses (Fang and Zou, 2009),(Theodosiou et al., 2012). Marketing dynamic capabilities refer to the responsiveness and efficiency of cross-functional business processes for creating and delivering superior customer value and consequently, sustained competitive advantage (Fang and Zou, 2009). Marketing dynamic capabilities are different from market orientation. Market orientation embodies the organizational culture and philosophy about the importance of satisfying customer needs, whereas marketing dynamic capabilities are operational processes that implement the philosophy, satisfy customer needs and respond to market changes (Narver and Slater, 1990), (Fang and Zou, 2009). Indeed, market orientation is the precursor of marketing dynamic capabilities. The organizational culture that focuses on creating customer values guides the organizational activities and processes in terms of product development, customer relationship management, and supply chain management to coordinate, integrate, and deploy inter-functional and inter-organizational resources and competences. In this regards, developing market-oriented business culture may contribute to the idiosyncratic cross-functional processes coordination and integration. According to Day (1994) market-oriented organizations seem to have superior market-sensing, customerlinking, and channel-bonding capabilities. By studying the findings of previous research, it can be seen that market orientation has an impact on marketing capabilities, some of which
The Role of Marketing

Resources and Marketing

Dynamic Capabilities 


\begin{tabular}{ll}
\hline \hline GBR \\
Vol. 16 \\
33
\end{tabular}

are listed below.

Market orientation helps companies in developing and expanding dynamic market capabilities (Wang et al., 2013). Also, market orientation affects organizational performance indirectly through marketing capabilities (Takata, 2016). Market orientation, through an active and accountable approach, affects market performance (Herhausen, 2016), financial and nonfinancial performance (Lee et al., 2015), and overall company performance (Hayati and Rukhviyanti, 2015). Market orientation, also affects customer acquisition and maintenance directly and indirectly through innovation (Rakthin, 2016). Finally, market orientation affects competitive advantage (Jogaratnam, 2017). According to these findings, three hypotheses have been developed as followed.

Hypothesis 1:

H0: Market orientation does not affect market sensing capability significantly.

H1: Market orientation affects market sensing capability significantly.

Hypothesis 2:

H0: Market orientation does not affect market learning capability significantly.

H1: Market orientation affects market learning capability significantly.

Hypothesis 3:

H0: Market orientation does not affect customer-linking capability significantly.

H1: Market orientation affects customer-linking capability significantly.

Managerial capabilities are considered as internal capabilities that can be categorized through traditional operational lines and include organizational and decisional processes management capabilities and organization design (Srockovic, 2017). Dynamic managerial capability is a concept explaining difference in managers decision-making in companies that result in different levels of performance, especially in changing business conditions (Woods et al., 2015). Such a capability is fundamental ability of any person leads to effective performance. This capability affects organizational performance through supporting marketing capabilities (Hooley, 2005). Sok et al. (2017) point out that marketing resources (such as managerial capabilities) affect organizational performance through marketing capabilities. Accordingly, three hypotheses have been developed as followed.

Hypothesis 4:

H0: Managerial capabilities do not affect market sensing capability significantly.

H1: Managerial capabilities affect market sensing capability significantly.

Hypothesis 5:

H0: Managerial capabilities do not affect market learning capability significantly. H1: Managerial capabilities affect market learning capability significantly.

Hypothesis 6 :

H0: Managerial capabilities do not affect customer linking capability significantly.

H1: Managerial capabilities affect customer linking capability significantly.

Market sensing capability provide marketing managers with a diversified information about markets, customers, competitors, and processes. Indeed, market sensing is a set of processes that create, disseminate, and save knowledge of customers, competitors, products, distribution channel members, and procedures (Odhiambo et al., 2015). Comprehensive knowledge helps organizations to promote customer relationships and its revenues and provide target markets with a diversified range of goods and services. It can be said that market knowledge is a type of organizational competency (Ming-Tien and Chia-Mei, 2004). Customer information, which is derived from market sensing capabilities, provide managers with an insight that increase market share and recognize market opportunities. Accordingly, two hypotheses have been developed as followed. 
Hypothesis 8:

H0: Market sensing capability does not affect market performance significantly.

H1: Market sensing capability affects market performance significantly.

Learning and knowledge processes is a necessary step, which explain differences in performance, is followed by many organizations. Companies, which have top market learning capabilities, can recognize untouched markets and satisfy their needs and wants (Morgan, 2009). Review of past studies revealed different views about the relationship among learning, knowledge, and organizational performance. Therefore, it is possible to find some thoughts to confirm the relationship between learning capability and organizational performance (Prieto and Revilla, 2006). For example, Siu et al. (2005) found that performance is influenced by learning and different types of knowledge. All in all, past studies confirm that learning affects business performance (Zollo and Winter, 2002). Accordingly, two hypotheses have been developed as followed.

Hypothesis 9:

H0: Market learning capability does not affect customer performance significantly.

H1: Market learning capability affects customer performance significantly.

Hypothesis 10:

H0: Market learning capability does not affect market performance significantly.

H1: Market learning capability affects market performance significantly.

Customer-linking capabilities include the ability to identify customer wants and requirements together with the capabilities to create and build appropriate relationships with those customers (Hooley et al., 2005). customer performance is conceptualized as a performance which can enhance through continuous relationship between the customer and an enterprise. Customer performance consists of customer acquisition, customer maintenance, customer satisfaction, customer awareness, customer image about the company and etc (Lee et al., 2008, Hajipour et al. 2010). Similar to customer performance, market performance is also a key indicator that reflects business performance. Market performance can be shown by the increase of market share. Guanxi has been proven to have a positive impact on market channels (Zhuang et al., 2010) and develops a firm's effectiveness and responsive capability. Therefore, it can be understood that well-developed customer-linking capabilities are likely to lead to higher levels of customer satisfaction and subsequently loyalty (Dick and Basu, 1994) and also market share, which are the main goals of customer and market performance.

Hypothesis 11:

H0: Customer-linking capability does not affect customer performance significantly.

H1: Customer-linking capability affects customer performance significantly.

Hypothesis 12:

H0: Customer-linking capability does not affect market performance significantly.

H1: Customer-linking capability affects market performance significantly.

Customer performance is important for improving company overall performance, since it leads to customer satisfaction and loyalty (Agostinin and Nosella, 2016). Reviewing the literature tells us that customer satisfaction and loyalty improve company performance (Jayachandran et al., 2005). On the other hand, market performance is determined based on the market share and sales criteria (Nemkova, 2017). Based on the review of literature, 


\section{Hypothesis 14:}

H0: Market performance does not affect financial performance significantly. H1: Market performance affects financial performance significantly.

Based on above review of literature, the conceptual model of this study has been developed as followed (Figure 1).

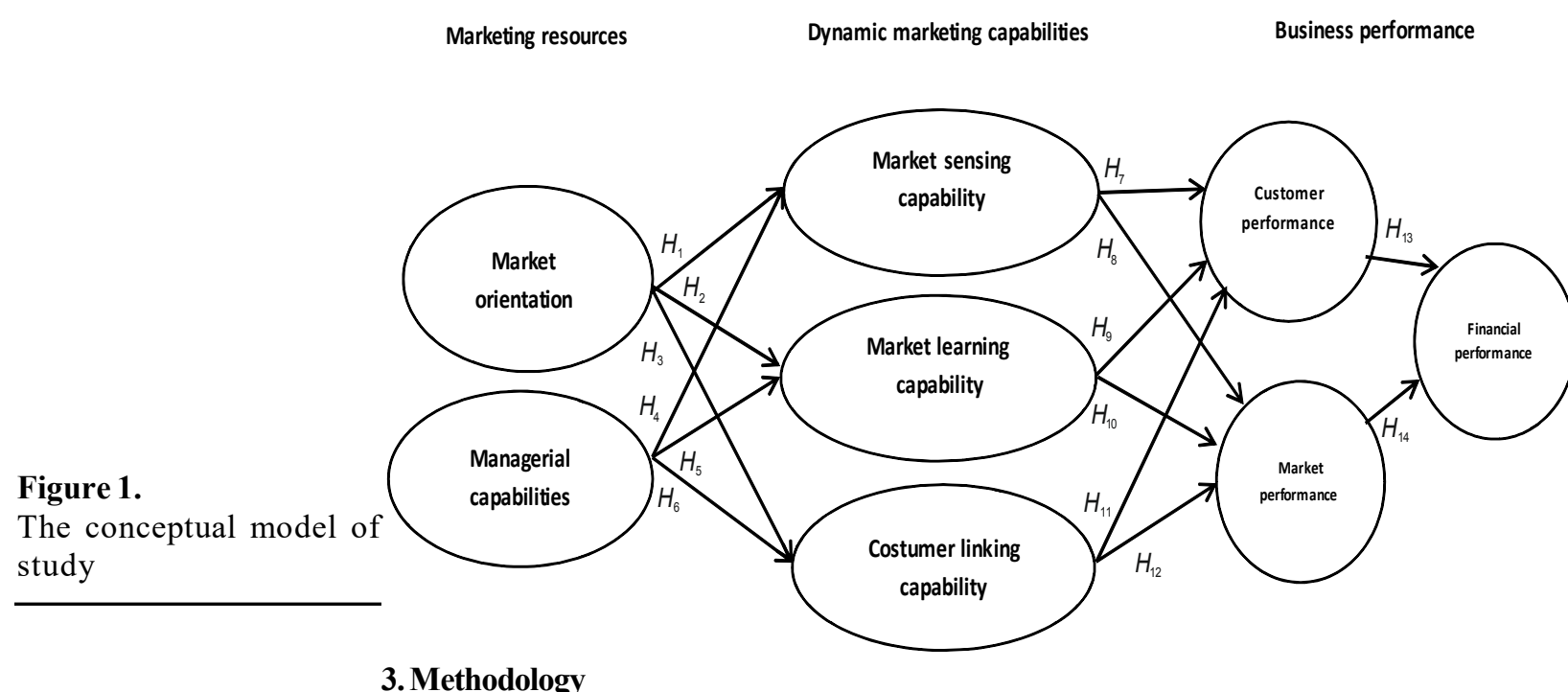

\section{Methodology}

3.1 Population and sample

The statistical population of this study consists of insurance companies in Ardabil City of Iran. The insurance companies of this city include Iran, Sina, Pasargad, Karafarin, Dana, Dey, Arman, Novin, Taavon, parsian, Asian, Alborz, Razi, Ma, and Moallem companies. The companies include 170 employees in the data-collection period of this study. Because the population is limited and its members are available for researcher, all of them were surveyed. For this purpose, 170 questionnaires were distributed and finally 127 ones have been indicated completely by respondents. Regarding the criteria for selecting companies, it should be noted that since the number of these companies was not large, all of them were selected then researchers went to the branches supervisions and distributed the questionnaires among employees who tended to cooperate so reluctant employees were removed from the statistical population.

\subsection{Variables measurement}

In order to collect the data in this study, both library and field study methods were used by researchers. In the first step (library study), the researcher reviewed the literature and past studies. In the second step (field study), a self-administrated questionnaire has been used. The questionnaire consists of two parts: demographic characteristics of respondents (age, gender, job experience, education, and organizational position) and main variables (marketing resources, dynamic marketing capabilities, and business performance). Variables and their dimensions and questions are presented in table 2 . It should be noted that the questionnaire has been developed in Likert five-point scale in which 1: strongly disagree 2: disagree 3: neutral 4: agree and 5: strongly agree. 


\begin{tabular}{|c|c|c|c|c|}
\hline Variables & Dimensions & $\begin{array}{c}\text { Number of } \\
\text { questions }\end{array}$ & Reference & \multirow{3}{*}{$\begin{array}{r}\text { The Role of Marketing } \\
\text { Resources and Marketing } \\
\text { Dynamic Capabilities } \\
36\end{array}$} \\
\hline \multirow[t]{2}{*}{ Marketing resource } & Market orientation & 7 & Hooley ret al. (2005) & \\
\hline & Managerial capabilities & 3 & Hooley ret al. (2005) & \\
\hline \multirow{3}{*}{$\begin{array}{c}\text { Dynamic marketing } \\
\text { capabilities }\end{array}$} & Market sensing capabilities & 5 & Morgan et al. (2009) & \multirow{6}{*}{$\begin{array}{l}\text { Table } 1 . \\
\text { Variables, dimensions, and } \\
\text { questions }\end{array}$} \\
\hline & Market learning capabilities & 4 & Mikalef ret al. (2017) & \\
\hline & Customer-linking capabilities & 5 & Hooley ret al. (2005) & \\
\hline \multirow[t]{3}{*}{ Business performance } & Customer performance & 3 & Hooley ret al. (2005) & \\
\hline & Market performance & 2 & Hooley ret al. (2005) & \\
\hline & Financial performance & 3 & Hooley ret al. (2005) & \\
\hline
\end{tabular}

3.3 Data analysis methods

In order to analyze the data and test the hypotheses, Partial Least Square method has been used in the Smart PLS. there are several reasons for using PLS rather than other methods. The main reason is that PLS is better for analyzing the data of small samples. Another reason is that PLS is better for analyzing abnormal data. Like to other structural equation models, Partial Least Square model consists of a structural part that show the relationship between manifested variables and a measurement component that reflect the relationship between manifested variables and their revealing variables. Indeed, three steps should be passed to test the hypotheses: 1 . Fitness of measurement model (the relationships between questions and manifested variable), 2. Fitness of structural model (the relationships between manifested variables), and 3. Fitness of overall model. Measurement model is a model in which the relationships between manifested and revealing variables are considered. In order to investigate the fitness of measurement models, the following criteria can be used (Mesrabadi et al., 2013; Mohammadbeigi et al., 2006):

1. Significance of factor loadings between questions and manifested variables that show the relationship between every question and its variable. The factor loading and tvalue should be more than 0.4 and 1.96 respectively.

2. Reliability that is measured based on the Cronbach's Alpha Coefficient and Composite Reliability. Both of Cronbach's Alpha Coefficient and Composite Reliability are between 0 and 1 . If the coefficients is less than 0.7 , reliability is poor; if it is between 0.7 and 0.8 , reliability is nearly good; and if it is more than 0.8 , reliability is good.

3. The validity that is measured based on the convergent and divergent validities. In the present study, convergent validity has been used for measuring variable explanation rate through measurement instrument. Convergent validity, which is measured based on the Average Extracted Variance (AVE), should be more than 0.5. On the other hand, divergent validity is used for measuring degree of interaction between questions of every variable. Indeed, divergent validity is complementary of convergent validity. In order to achieve convergent validity, square root of Average Extracted Variance (AVE) should be calculated. It should be noted that convergent validity should be more than correlation of other variables' questions.

Structural model is a model in which the relationship between revealing and manifested variables are considered. Indeed, structural model investigates only the manifested variables and their relationships. According to Mesrabadi et al. (2013) and Mohammadbeigi et al. (2006), criteria of structural model test include the followings:

1. Coefficient of determination $\left(\mathrm{R}^{2}\right)$ of invertebrate variables: This is a criterion that show the effect of exogenous variables on invertebrate variable. In this regard, 0.19, 0.33 , and 0.67 are respectively poor, medium, and top values for $\mathrm{R}^{2}$.

2. Predictive Relationship Index $\left(\mathrm{Q}^{2}\right)$ : The index shows the model forecasting capability of dependent variables. In this regard, $0.02,0.15$, and 0.35 have respectively low, moderate, and high forecasting capability.

3. Effect size criterion $\left(f^{2}\right)$ : The criterion determines intensity of the relationship between constructs. Higher levels of this criterion refers to high intensity of relationship. In 


\section{GBR}

Vol. 16

37

this regard, $0.02,0.15$, and 0.35 refer to low, moderate, and high effect respectively. The criterion can be calculated for endogenous variable that is affected by more than a variable like to dynamic marketing capabilities and financial performance in this study.

Finally, Goodness of Fit is another criterion for measuring model fitness. Based on this criterion, $0.01,0.25$ and 0.36 are respectively poor, moderate, and high fitness values.

\section{Results}

4.1 Demographic characteristics of respondents

A summary of demographic characteristics of the respondents (including age, gender, job experience, education, and organizational position) have been presented in table 2 .

Table 2.

Summary of respondents demographic characteristics

\begin{tabular}{|c|c|c|c|c|c|c|c|}
\hline Age & $\%$ & $\begin{array}{c}\text { Job } \\
\text { experience }\end{array}$ & $\%$ & Education & $\%$ & $\begin{array}{c}\text { organizational } \\
\text { position }\end{array}$ & $\%$ \\
\hline$\leq \mathbf{3 0}$ & 23 & $\leq \mathbf{5}$ & 27 & $\begin{array}{c}\text { High } \\
\text { school }\end{array}$ & 4 & Expert & 64 \\
\hline $\mathbf{3 0 - 4 0}$ & 52 & $\mathbf{5 - 1 0}$ & 40 & $\begin{array}{c}\text { Associate } \\
\text { degree }\end{array}$ & 12 & Top expert & 11 \\
\hline $\mathbf{4 0 - 5 0}$ & 21 & $\mathbf{1 0 - 1 5}$ & 18 & M.A. & 54 & $\begin{array}{c}\text { Head of } \\
\text { department }\end{array}$ & 10 \\
\hline $\mathbf{5 0 \leq}$ & 4 & $\mathbf{1 5} \leq$ & 15 & $\begin{array}{c}\text { Post } \\
\text { graduate }\end{array}$ & 30 & Vice president & 6 \\
\cline { 5 - 8 } & & & & & CEO & 9 \\
\hline
\end{tabular}

4.2 Reliability and validity of questionnaire

As indicated in research methodology section, total structural model consists of two sections: measurement and structural models. Before testing the conceptual mode of study, it is necessary to confirm fitness of measurement model. For this purpose, different criteria of model should be examined and confirmed: construct validity, descriptive validity, convergent validity, composite reliability, and Cornbrash's Alpha Coefficient. The calculated are indicated in table 3 .

\begin{tabular}{|c|c|c|c|c|c|c|}
\hline $\begin{array}{l}\text { Manifested } \\
\text { variable }\end{array}$ & Revealing variable (question) & $\begin{array}{l}\text { Factor } \\
\text { loading }\end{array}$ & $t$ & $\begin{array}{l}\text { Composite } \\
\text { reliability }\end{array}$ & $\begin{array}{l}\text { Average } \\
\text { extracted } \\
\text { variance }\end{array}$ & $\begin{array}{l}\text { Cronbach's } \\
\text { Alpha } \\
\text { Coefficient }\end{array}$ \\
\hline \multirow{7}{*}{$\begin{array}{c}\text { Market } \\
\text { orientation }\end{array}$} & $\begin{array}{l}\text { Our commitment to serv ing customers is } \\
\text { closely monitored. }\end{array}$ & .704 & 12.717 & \multirow{7}{*}{.881} & \multirow{7}{*}{.517} & \multirow{7}{*}{.842} \\
\hline & $\begin{array}{l}\text { Objectives and strategies are driven by } \\
\text { creation of customer satisfaction }\end{array}$ & .515 & 6.288 & & & \\
\hline & $\begin{array}{l}\text { Competitive strategies are based on } \\
\text { understanding customer needs }\end{array}$ & .791 & 18.052 & & & \\
\hline & $\begin{array}{l}\text { Functions are integ rated to serve market } \\
\text { needs }\end{array}$ & .664 & 12.099 & & & \\
\hline & $\begin{array}{l}\text { Strategies are driven by increasing value } \\
\text { for customers }\end{array}$ & .767 & 16.939 & & & \\
\hline & $\begin{array}{l}\text { Customer satisfaction is systematically and } \\
\text { frequently assessed }\end{array}$ & .684 & 11.264 & & & \\
\hline & $\begin{array}{l}\text { Managers understand how employees } \\
\text { contribute to value for customers }\end{array}$ & .740 & 16.283 & & & \\
\hline \multirow{3}{*}{$\begin{array}{l}\text { Managerial } \\
\text { capabilities }\end{array}$} & $\begin{array}{l}\text { Financial management of this company is } \\
\text { effective. }\end{array}$ & .762 & 16.177 & & & \\
\hline & $\begin{array}{l}\text { Human resource management is effective } \\
\text { in this company. }\end{array}$ & .776 & 13.276 & & & \\
\hline & $\begin{array}{l}\text { Operations management expertise is good } \\
\text { in this company. }\end{array}$ & .794 & 18.826 & & & \\
\hline
\end{tabular}




\begin{tabular}{|c|c|c|c|c|c|c|c|}
\hline \multirow{5}{*}{$\begin{array}{l}\text { Market sensing } \\
\text { capabilities }\end{array}$} & $\begin{array}{l}\text { The company learning capabilities are } \\
\text { effective in understanding customers' } \\
\text { needs and wants. }\end{array}$ & .740 & 15.075 & \multirow{5}{*}{.836} & \multirow{5}{*}{.506} & \multirow{5}{*}{.755} & \multirow{5}{*}{$\begin{array}{r}\text { The Role of Marketing } \\
\text { Resources and Marketing } \\
\text { Dynamic Capabilities } \\
38\end{array}$} \\
\hline & $\begin{array}{l}\text { The company recognize competitors' } \\
\text { strategies and tactics efficiently. }\end{array}$ & .690 & 12.204 & & & & \\
\hline & $\begin{array}{l}\text { The comp any's capabilities in customer } \\
\text { services procedures are appropriate. }\end{array}$ & .665 & 9.700 & & & & \\
\hline & $\begin{array}{l}\text { The company is effective in recognizing } \\
\text { market trends. }\end{array}$ & .703 & 11.310 & & & & \\
\hline & $\begin{array}{l}\text { The company is able to recognize its } \\
\text { environment. }\end{array}$ & .666 & 12.152 & & & & \\
\hline \multirow{4}{*}{$\begin{array}{l}\text { Marker learning } \\
\text { capabilities }\end{array}$} & $\begin{array}{l}\text { The c ompany is effective in recognizing, } \\
\text { evaluating, and achieving the information } \\
\text { and knowledge about competitive markets. }\end{array}$ & .790 & 22.074 & \multirow{4}{*}{.879} & \multirow{4}{*}{.686} & \multirow{4}{*}{.842} & \\
\hline & $\begin{array}{l}\text { The company transforms the information } \\
\text { of competitive market to new knowledge. }\end{array}$ & .623 & 22.670 & & & & \\
\hline & $\begin{array}{l}\text { The company achieves new information } \\
\text { and knowledge about competitive markets. }\end{array}$ & .872 & 42.725 & & & & \\
\hline & $\begin{array}{l}\text { The company uses new information and } \\
\text { knowledge of competitive markets in decisions }\end{array}$ & .826 & 25.293 & & & & \\
\hline \multirow{4}{*}{$\begin{array}{l}\text { Customer- } \\
\text { linking } \\
\text { capabilities }\end{array}$} & $\begin{array}{l}\text { Superior levels of customer service and } \\
\text { support can be seen in this company. }\end{array}$ & .817 & 15.875 & \multirow{4}{*}{.832} & \multirow{4}{*}{.501} & \multirow{4}{*}{.749} & \\
\hline & $\begin{array}{l}\text { The company has relationships with key } \\
\text { target customers. }\end{array}$ & .618 & 7.263 & & & & \\
\hline & $\begin{array}{l}\text { The company is good at understanding } \\
\text { what customer needs and requirements are. }\end{array}$ & .576 & $6 / 859$ & & & & \\
\hline & $\begin{array}{l}\text { The company is good at cr } \\
\text { relationships with customers }\end{array}$ & .722 & 11.522 & & & & \\
\hline \multirow{4}{*}{$\begin{array}{l}\text { Customer } \\
\text { performance }\end{array}$} & $\begin{array}{l}\text { The company is good in levels of customer } \\
\text { loyalty compared to competitor }\end{array}$ & .805 & 22.383 & & & & \\
\hline & $\begin{array}{l}\text { The company is good in levels of customer } \\
\text { satisfaction compared to last year }\end{array}$ & .716 & 12.524 & & & & \\
\hline & $\begin{array}{l}\text { The company is good in levels of customer } \\
\text { loyalty compared to last year }\end{array}$ & .737 & 12.178 & & & & \\
\hline & $\begin{array}{l}\text { The company is good in maintaining and } \\
\text { developing relationships with customers. }\end{array}$ & .814 & 19.270 & & & & \\
\hline \multirow{2}{*}{$\begin{array}{c}\text { Market } \\
\text { performance }\end{array}$} & $\begin{array}{l}\text { Sales volume achieved compared to } \\
\text { Competitors is good. }\end{array}$ & .879 & 40.403 & \multirow{2}{*}{.883} & \multirow{2}{*}{.792} & \multirow{2}{*}{.737} & \multirow{5}{*}{$\begin{array}{l}\text { Table } 3 . \\
\text { Results of construct } \\
\text { validity, descriptive validity, } \\
\text { convergent validity, and } \\
\text { Cronbach's Alpha }\end{array}$} \\
\hline & $\begin{array}{l}\text { Market share compared to competitors is } \\
\text { good. }\end{array}$ & .900 & 43.912 & & & & \\
\hline \multirow{3}{*}{$\begin{array}{l}\text { Financial } \\
\text { performance }\end{array}$} & $\begin{array}{l}\text { Overall profit levels achieved compared to } \\
\text { competitors is good. }\end{array}$ & .850 & 31.705 & \multirow{3}{*}{.837} & \multirow{3}{*}{.633} & \multirow{3}{*}{.709} & \\
\hline & $\begin{array}{l}\text { Profit margins compared to competitors is } \\
\text { good. }\end{array}$ & .701 & 9.743 & & & & \\
\hline & $\begin{array}{l}\text { Return on investment compared to } \\
\text { competitors is good. }\end{array}$ & .823 & 20.504 & & & & \\
\hline
\end{tabular}




\section{GBR}

Vol. 16

39
The values of 0.4 and 0.5 have been considered as accepted cut points of factor loading (Hulland, 1999; Rivard and Huff, 1988). In the present study, 0.5 has been selected. The results of factor loading (table 3 ) reveal that factor loadings of all questions are more than .5 and also t-values are more 1.96 (sig: .05). Based on the results of table 3 , it can be said that the questionnaire has good validity.

When average extracted variance is more than critical value (.5), it can be said that the questionnaire has descriptive validity. Also there are three prerequisites for confirming convergent validity of questionnaire: 1 . the composite reliability value is more than $0.7,2$. the average extracted variance is more than 0.5 , and 3 . composite reliability value is more than average extracted variance. If composite reliability value is more than .7 , it can be said that the question has good internal reliability for measurement models. If the value is .6, then it tells us that the questions has not acceptable reliability. Finally, .7 is an accepted cut point for Cronbach's Alpha Coefficient. Based on the results of table 4, the questionnaire has good descriptive validity, convergent validity, and reliability.

Table 4.

\begin{tabular}{|c|c|c|c|c|c|c|c|c|}
\hline Constructs & $\begin{array}{c}\text { Market } \\
\text { orientation }\end{array}$ & $\begin{array}{l}\text { Managerial } \\
\text { capabilities }\end{array}$ & $\begin{array}{c}\text { Market } \\
\text { sensing } \\
\text { capabilities }\end{array}$ & \begin{tabular}{|c|} 
Market \\
learning \\
capabilities
\end{tabular} & $\begin{array}{l}\text { Customer- } \\
\text { linking } \\
\text { capabilities }\end{array}$ & $\begin{array}{c}\text { Customer } \\
\text { performance }\end{array}$ & $\begin{array}{c}\text { Market } \\
\text { performance }\end{array}$ & $\begin{array}{c}\text { Financial } \\
\text { performance }\end{array}$ \\
\hline $\begin{array}{c}\text { Market } \\
\text { orientation }\end{array}$ & .72 & & & & & & & \\
\hline $\begin{array}{l}\text { Managerial } \\
\text { capabilities }\end{array}$ & .58 & .82 & & & & & & \\
\hline $\begin{array}{c}\text { Market } \\
\text { sensing } \\
\text { capabilities }\end{array}$ & .57 & .46 & .71 & & & & & \\
\hline $\begin{array}{c}\text { Market } \\
\text { learning } \\
\text { capabilities }\end{array}$ & .55 & .50 & .60 & .83 & & & & \\
\hline $\begin{array}{c}\text { Customer- } \\
\text { linking } \\
\text { capabilities }\end{array}$ & .65 & .61 & .55 & .54 & .71 & & & \\
\hline $\begin{array}{c}\text { Customer } \\
\text { performance }\end{array}$ & .50 & .49 & .52 & .50 & .58 & .77 & & \\
\hline $\begin{array}{c}\text { Market } \\
\text { performance }\end{array}$ & .60 & .61 & .59 & .66 & .58 & .52 & .89 & \\
\hline $\begin{array}{c}\text { Financial } \\
\text { performance }\end{array}$ & .46 & .36 & .51 & .39 & .37 & .49 & .49 & .80 \\
\hline
\end{tabular}

As indicated in table 4, the AVE value is more than other values. Therefore, it can be said that the manifested variables have interaction with their related questions. In other words, the results of this table show the questionnaire has good divergent validity.

\subsection{Conceptual model estimation}

As indicated previously, the conceptual model of this study has been tested by Partial Least Square. Figures 2 and 3 show the model and its revealing and manifested variables. Summary of t-values and path coefficients are presented in table 5.

Based on the results of table 4, t-values tell us that all hypotheses (except hypotheses 7, 10, and 12) are accepted. According to path coefficients, market orientation (as the first dimension of marketing resources) affects significantly market sensing capability, market learning capability, and customer-linking capability. Also the effect of managerial capabilities (as another dimension of marketing resources) on the market sensing capability, market learning capability, and customer-linking capability were found significant. The findings showed that market sensing capabilities affect market performance significantly and do not affect customer performance significantly. Also market learning capabilities affect significantly customer performance and do not affect market performance. A significant effect was found 


\begin{tabular}{|c|c|c|c|c|c|c|}
\hline Hypothesis & Independent variable & Dependent variable & Path coefficient & t-value & Result & \multirow{3}{*}{$\begin{array}{r}\text { The Role of Marketing } \\
\text { Resources and Marketing } \\
\text { Dynamic Capabilities } \\
40\end{array}$} \\
\hline H1 & market orientation & market sensing capability & .463 & 5.287 & Accepted & \\
\hline $\mathrm{H} 2$ & market orientation & market learning capability & 396 & 4.544 & Accepted & \\
\hline $\mathrm{H} 3$ & market orientation & customer lin king capability & .446 & 5.412 & Accepted & \\
\hline $\mathrm{H} 4$ & managerial capabilities & market sensing capability & 277 & 2.810 & Accepted & \\
\hline $\mathrm{H} 5$ & managerial capabilities & market learning capability & .255 & 2.811 & Accepted & \\
\hline $\mathrm{H} 6$ & Managerial capabilities & customer linking capability & .358 & 3.898 & Accepted & \\
\hline H7 & market sensing capabilities & customer performance & .128 & 1.513 & Rejected & \\
\hline $\mathrm{H} 8$ & market sensing capabilities & market performance & .298 & 2.238 & Accepted & \\
\hline H9 & market learning capabilities & customer performance & .210 & 2.403 & Accepted & \\
\hline $\mathrm{H} 10$ & market learning capabilitie $\mathrm{s}$ & market performance & .092 & .940 & Rejected & \\
\hline H11 & customer-linking capabilities & customer performance & .442 & 4.836 & Accepted & \\
\hline $\mathrm{H} 12$ & customer-linking capabilities & market performance & .078 & .973 & Rejected & \\
\hline $\mathrm{H} 13$ & customer performance & financial performance & .206 & 3.363 & Accepted & \multirow{2}{*}{$\begin{array}{l}\text { Table } 5 \text {. } \\
\text { Path coefficients of model }\end{array}$} \\
\hline H14 & market performance & financial performance & .601 & 11.019 & Accepted & \\
\hline
\end{tabular}

between customer-linking capabilities and customer performance. Finally, the findings showed that customer and market performance affect financial performance of companies.

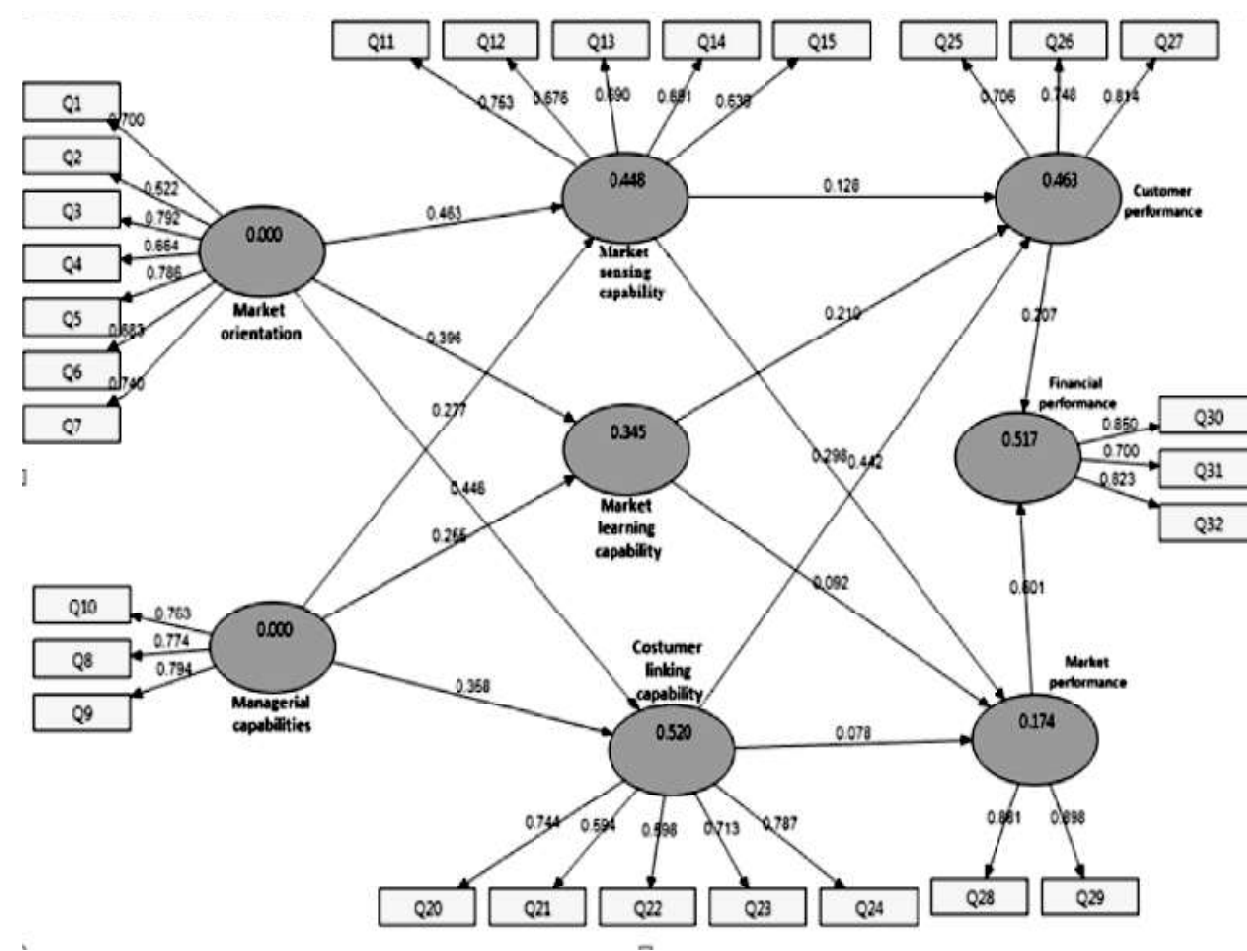

Figure 2.

Path coefficients and coefficients of determination 


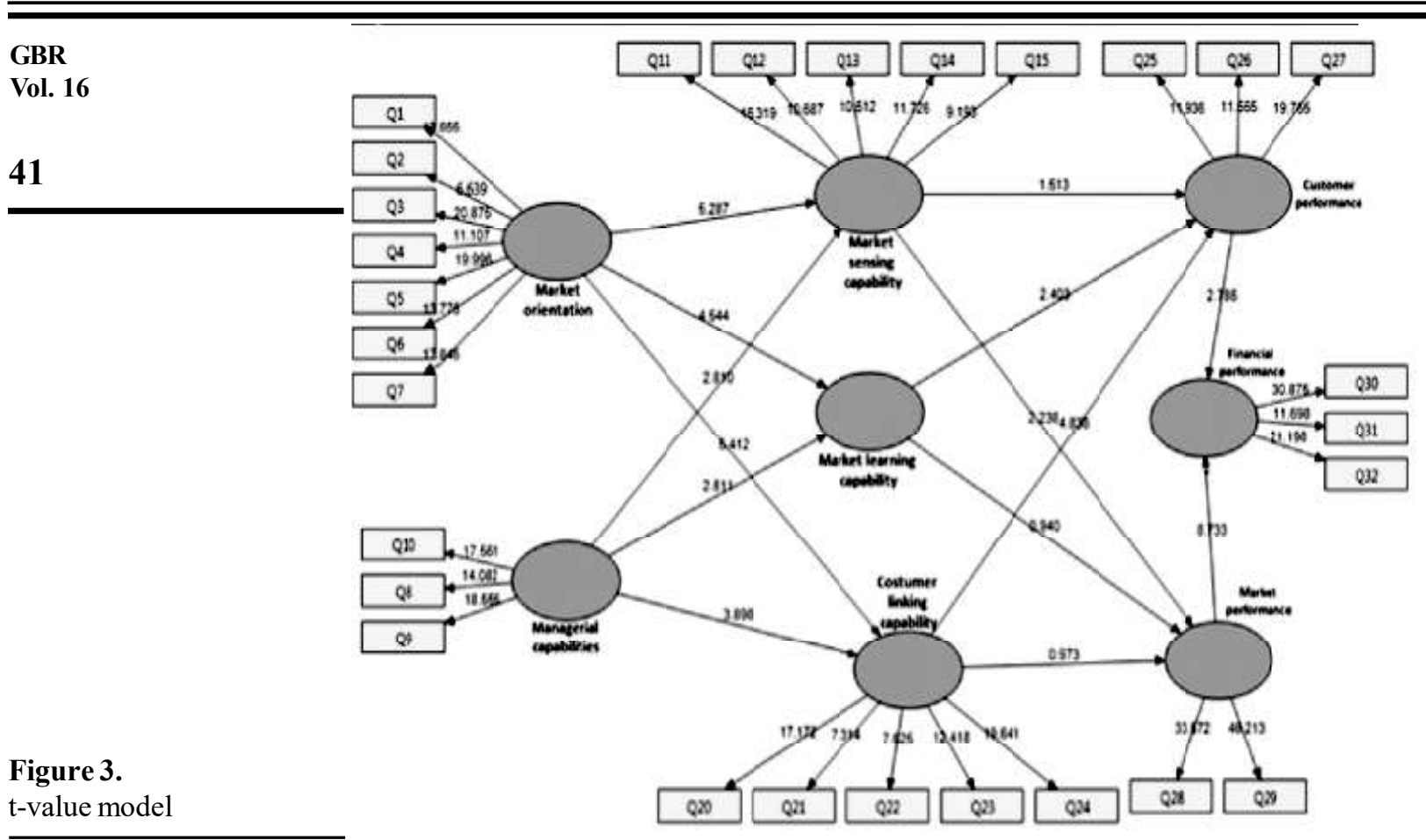

t-value model

4.4 Model fitness

After investigating fitness of measurement models in Partial Least Square, it is necessary to examine fitness of structural model. The fitness criteria of structural model have been presented in table 6 .

Table 6.

\begin{tabular}{|c|c|c|c|c|}
\hline Constructs/paths & $\mathbf{R}^{2}$ & $\mathbf{Q}^{2}$ & $\mathbf{f}^{2}$ & GOF \\
\hline Market orientation & - & .51 & - & \multirow{2}{*}{.6} \\
\hline Managerial capabilities & - & .66 & - & \\
\hline Market sensing capabilities & .758 & .36 & - \\
\hline Market learning capabilities & .726 & .50 & - \\
\hline customer performance & .717 & .33 & - \\
\hline Market performance & .436 & .23 & - \\
\hline Financial performance & .158 & .72 & - \\
\hline (dynamic market capabilities < market orientation) $\mathbf{f}^{2}$ & .516 & .20 & - \\
\hline (dynamic market capabilities < managerial capabilities) $\mathbf{f}^{2}$ & - & - & .21 \\
\hline (financial performance < customer performance) $\mathbf{f}^{2}$ & - & - & .16 \\
\hline (financial performance $<$ market - performance) $\mathbf{f}^{2}$ & - & - & .13 & \\
\hline
\end{tabular}

The coefficient of determination $\left(\mathrm{R}^{2}\right)$ is one of the important criteria of structural model fitness. It is a criterion that show the effect of exogenous variable on endogenous variable. The values $.19, .33$, and .67 are considered as low, moderate, and top values for this criterion (Gye-Soo, 2016). According to table 6, the coefficients of dynamic marketing capabilities, customer performance, market performance, and financial performance are $.585, .436, .158$, and .516 respectively. The values are low and it can be said that the model has fairly good fitness. Based on the $\mathrm{f}^{2}$, intensity of effect of market orientation and managerial capabilities on dynamic marketing capabilities are .21 and .13 respectively. Also intensity of effect of customer performance and market performance on financial performance are .13 and .13 respectively. Finally, $\mathrm{Q}^{2}$ of intrinsic constructs of model refer to its good estimation. Finally, 


\section{Discussion}

The results of this study showed that market orientation affects dynamic marketing capabilities significantly. In other words, companies can success in implementing and applying dynamic marketing capabilities by using market orientation approach. Based on adoption of marketoriented approach, it is expected that companies focus on external factors such as customers rather than internal factors. This leads to sensing, learning, and more relationships with market factors. This part of our findings is consistent with past studies results such as Hooley et al. (2005), Wang et al. (2013), and Takata (2016). Another part of our findings showed that effect of managerial capabilities on dynamic marketing capabilities and its triple dimensions is significant. But the intensity of this effect is less than the effect of market orientation. The reason is that managerial capabilities not only affect dynamic marketing capabilities directly, but also affect it indirectly through market orientation. It can be said that having an empowered management team paves the ground for applying dynamic marketing capabilities. This part of our findings is supported by past studies findings such as Hooley et al. (2005). Therefore, it can be concluded that top managerial capabilities play an important role in promoting dynamic marketing capabilities and enabling organizations in expanding market orientation culture. The significant effect of managerial capabilities on dynamic marketing capabilities also was found in past studies such as Hooley et al. (2005), Menguc et al. (2013), Sok et al. (2017), and Teece (2017).

The effect of dynamic marketing capabilities on nonfinancial performance (including customer and market performances) is confirmed in some cases and is rejected in others. All in all, the effect of dynamic marketing capabilities on customer performance and market performance was supported in past studies such as Evans and Dissanayake (1999), Zollo and Winter (2002), Ming-Tien and Chia-Mei (2004), Song et al. (2007), Gebhardt et al. (2006), Morgan (2009), Asikhia (2010), Odhiambo et al. (2015), and Takata (2016). It is expected that dynamic marketing capabilities affect financial criteria such as income and profitability. Marketing information systems is a process of analyzing and interpreting factors that affect customers' needs and wants. Also the response of marketing information systems may be in form of selecting target markets and developing suitable products based on the customers' needs and wants. Marketing knowledge is a set of structured information about markets, customers, competitors, and procedures. The marketing knowledge provides organizations with better customer relationships and more incomes. Also learning processes and procedures are considered as a necessary process that explain the differences in performance. Some studies of dynamic marketing capabilities have focused on nonfinancial performance and some others have considered financial performance. However, other researchers have studied performance in both financial and nonfinancial criteria. Since dynamic marketing capabilities are related to marketing performance, the authors of this study prefers to measure business performance based on customer, market, and financial performances. The results showed that improvement in customer and market performances lead to promoted financial performance. The findings of this part of our study are consistent with past findings such as Hooley et al. (2005), Karabulut (2015), Agostini and Nosella (2016), and Anning-Dorson (2017).

\section{Conclusion, recommendations and limitations}

Now a days, most industries and markets face competitive conditions, especially insurance industry. In such conditions, companies should use all opportunities to improve their business performance. In this regard, marketing resources and dynamic marketing capabilities are the main components of marketing information systems in businesses. The authors of this paper were determined to investigate the effect of marketing resources and dynamic marketing capabilities on business performance in insurance companies. The results of this study revealed that market orientation and managerial capabilities affect dynamic marketing capabilities and its dimensions (market sensing, market learning, and customer-linking capabilities). The results also showed that market learning and customer-linking capabilities 
affect business performance significantly. Finally, it was found that customer and market performances affect companies' financial performance. Based on the results of this study, it is suggested that marketing managers of insurance industry pathology shared culture of employees to create necessary changes in them for promoting market-oriented values. In other words, organizational culture of these companies should be changed so that customers' needs and wants and the effective environmental factors on them are considered as the main effective factors on organizational decisions. It should be noted that changes in structure of marketing department can be in form of decreasing organizational centralization, formality, and complexity so that marketing employees be empowered to recognize environmental changes as soon as possible and then act based on them to provide customers with diversified services.

Currently, dynamic marketing capabilities are considered as one of the determinant characteristics of knowledge enterprises. Accordingly, it is suggested that marketing managers create ongoing processes of market information and acquire marketing knowledge through developing dynamic marketing capabilities. As a result, marketing efforts will be improved and organizational goals can be achieved. Some of the main solutions for creating and promoting dynamic marketing capabilities have been suggested as followed: implementation of advanced marketing information systems, building specialist teams for monitoring environmental changes, applying modern organizational principles such as marketing processes reengineering for facilitating marketing information acquisition, and applying learning organizations principles. Also dynamic marketing capabilities have been considered as a variable with three dimensions: market sensing, market learning, and customer-linking capabilities. Organizations acquire necessary information through market sensing and then transform this information to knowledge by using market learning. Finally, they use the knowledge to effective communications and improve their performance. Accordingly, it is suggested that marketing managers of insurance companies consider market sensing, market learning, and customer-linking capabilities simultaneously. The reason is that market learning capabilities lead to customer-linking. Eventually it is recommended that insurance companies, strengthen appropriate marketing communications and increase customer service development, consider the needs and opinions of customers in improving their services, use a survey to identify their weaknesses and strengths (in terms of customers) and take action to dispel their weaknesses and reinforce their strengths, use creative advertising to promote their brand. Furthermore, since service quality has a significant important for customers, it is recommended that insurance companies increase the quality of their services (for example, pay attention to customer needs, provide timely services, order employees to be polite when dealing with customers, etc.). Holding workshops for employees can also be effective in improving activities. In addition to the issues raised, since sellers must clearly explain the service features and benefits to customers when they refer to buy insurance services, it is better for insurance companies to consider relevant training courses for sellers. In addition, company must provide incentives for customers to maintain their loyalty.

Future researchers are suggested to study other effective factors on dynamic marketing capabilities such as customer-orientated strategies, employee motivation systems, and even leadership. Such factors may affect development, maintenance, and expansion of dynamic marketing capabilities and their effects should be studied. The findings of these studies can be helpful in recognizing determinant components of implementation of dynamic marketing capabilities in organizations. Also it is suggested future authors investigate other potential outcomes of dynamic marketing capabilities such as brand equity, brand image, social responsibility, and etc. Also it is suggested that future studies focus on the effect of other marketing resources (such as human resources, reputation and reliability resources, information resources, and even physical resources) on dynamic marketing capabilities. In addition, future researchers are suggested to investigate the effect of strategic marketing capabilities, special marketing capabilities, inter-functional marketing capabilities, and marketing architecture capabilities on business performance. Finally, they are recommended to test the model used in this study in other industries and compare the 
results.

Like to other studies, there were some limitations in this study. Lack of comprehensive researches in this field is one of the main limitations of this study. Unfortunately, some of the respondents had not sufficient motivation to participate in survey and indicate the questionnaire. The survey has been done only in Ardabil (a city in north of Iran) and this limits generalization of its results. Finally, the authors used questionnaire as only datacollection instrument of this study that inevitably has its own limitations.

\section{References}

Agostini, L. and Nosella, A. (2016), "The central role of a company's technological reputation in enhancing customer performance in the B2B context of SMEs", Journal of Engineering and Technology Management, Vol. 42, pp. 1-14.

Akinova, I. (2000), "'Development of market orientation and competitiveness of Ukrainian firms", European Journal of Marketing, Vol. 34 No. 9, pp. 1128-1148.

Anning-Dorson, T. (2017), "Customer involvement capability and service firm performance: The mediating role of innovation", Journal of Business Research, Vol. 86, pp. 269-280

Asikhia, O. (2010), "Customer orientation and firm performance among Nigerian small and medium scale businesses", International Journal of Marketing Studies, Vol. 2 No. 1, pp. 197-212.

Cacciolatti, L. Lee, S.H. (2016), "Revisiting the relationship between marketing capabilities and firm performance: The moderating role of market orientation, marketing strategy and organizational power", Journal of Business Research, Vol. 69 No. 12, pp. 5597-5610.

Day, G.S. (2011), “Closing the marketing capabilities gap", Journal of Marketing, Vol. 75, 183-195.

Deshpande R. and Webster Jr, F.E. (1989), "Organizational culture and marketing: defining the research agenda", The Journal of Marketing, Vol. 53, pp. 3-15.

Evans, J.V. and Dissanayake, A. (1999), "Prospects for commercial satellite services at Q-and Vbands", Acta Astronautica, Vol. 44 Issue 7, pp. 737-743.

Gebhardt, Carpenter, G. and Sherry Jr, J. (2006), "Creating a market orientation: A longitudinal, multi-firm, and grounded analysis of cultural transformation", Journal of Marketing, Vol. 70 No. 4 , pp. 37-55.

Hayati, N. and Rukhviyanti, N. (2016), "Leadership Capability for Market Orientation and Learning Orientation and Its Impact on the Institution Performance and Competitiveness: A Case of STIE Indonesia", Procedia-Social and Behavioral Sciences, Vol. 219, pp. 291-298.

Herhausen, D. (2016), "Unfolding the ambidextrous effects of proactive and responsive market orientation", Journal of Business Research, Vol. 69 No. 7, pp. 2585-2593.

Hooley, G.J., Greenley, G.E., Cadogan, J.W. and Fahy, J. (2005), "The performance impact of marketing resources", Journal of Business Research, Vol. 58 No. 1, pp. 18-27.

Hulland, J. (1999), "Use of partial least squares (PLS) in strategic management research: A review of four recent studies", Strategic Management Journal, Vol. 20 No. 2, pp. 195-204.

Hunt, S.D. (2000), A General Theory of Competition: Resources, Competences, Productivity, Economic Growth, Sage Publications, London.

Jayachandran, S. Sharma, S. Kaufman, P. and Raman, P. (2005), "The role of relational information processes and technology use in customer relationship management", Journal of Marketing, Vol. 69 No. 4, pp. 177-192.

Jogaratnam, G. (2017), “The effect of market orientation, entrepreneurial orientation and human capital on positional advantage: Evidence from the restaurant industry", International Journal of Hospitality Management, Vol. 60, pp. 104-113.

Karabulut, A.T. (2015), "Effects of Innovation Strategy on Firm Performance: A Study Conducted on Manufacturing Firms in Turkey", Procedia-Social and Behavioral Sciences, Vol. 195, pp. 1338-1347.

Ketchen, D. Hult, G.T.M. (2011), "Marketing and organization theory: Opportunities for synergy", Journal of the Academy of Marketing Science, Vol. 39 No. 5, pp. 1-3.

Kozlenkova, I.V. Samaha, S.A. and Palmatier, R.W. (2014), "Resource-based theory in marketing", Journal of the Academy of Marketing Science, Vol. 42 No. 1, pp. 1-21.

Krasnikov, A. and Jayachandran, S. (2008), "The Relative Impact of Marketing, Research-andDevelopment, and Operations Capabilities on Firm Performance", Journal of Marketing, Vol. 72 No. 4, pp. 20-41.

Lee, Y.K. Kim, S.H. Seo, M.K. and Hight, S.K. (2015), "Market orientation and business performance: Evidence from franchising industry", International Journal of Hospitality Management, Vol. 44 , pp. 28-37.
The Role of Marketing

\section{sources and Marketing}

Dynamic Capabilities 


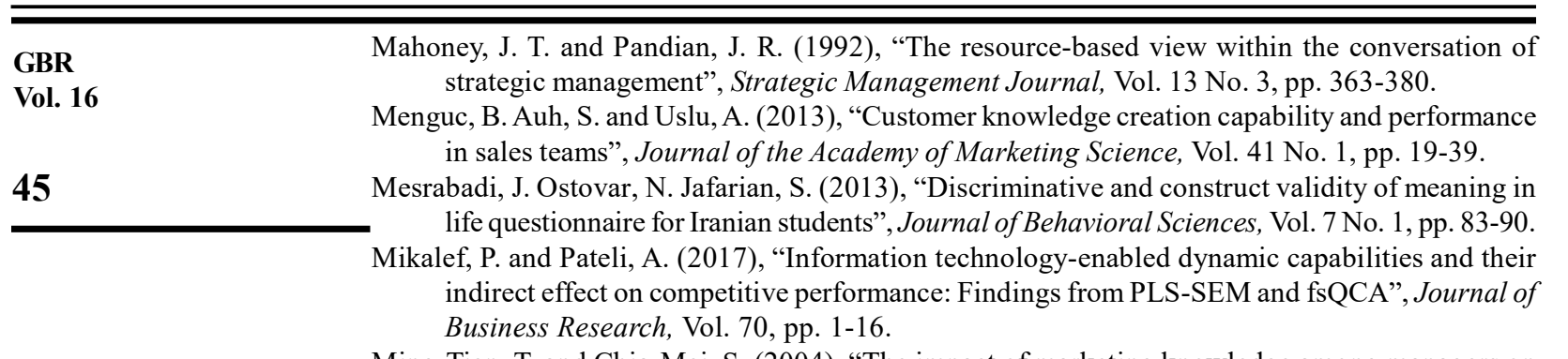

Ming-Tien, T. and Chia-Mei, S. (2004), "The impact of marketing knowledge among managers on marketing capabilities and business performance", International Journal of Management, Vol. 21 No. 4, pp. 524-530.

Mohammad Beighi, A., Mohammad Salehi, N., and Gol, M. A. (2014), "Validity and reliability of different measurement methods and instruments and their applications in applicable research in health", Journal of University of Medical Sciences, Vol. 13, pp. 1170-1153.

Morgan, N.A. (2012), "Marketing and business performance", Journal of the Academy of Marketing Science, Vol. 40 No. 1, pp. 102-119.

Morgan, N.A. Slotegraaf, R.J. and Vorhies, D.W. (2009), "Linking marketing capabilities with profit growth", International Journal of Research in Marketing, Vol. 26 No. 4, pp. 284-293.

Nemkova, E. (2017), "The impact of agility on the market performance of born-global firms: An exploratory study of the 'Tech City innovation cluster", Journal of Business Research, Vol. 80 No. 3, pp. 257-265.

Newbert, S. L. (2007), "Empirical research on the resource based view of the firm: An assessment and suggestions for future research", Strategic Management Journal, Vol. 28 No. 2, pp. 121 146.

O'Sullivan, D., Andrew, V.A. and Hutchinson, M. (2009), "Marketing performance measurement and firm performance", European Journal of Marketing, Vol. 43, pp. 843-862.

Odhiambo, O.J., Kibera, F. and Musyoka, R. (2015), "The influence of organizational culture and marketing capabilities on performance of microfinance institutions in Kenya" Journal of Marketing Management, Vol. 3 No. 1, pp. 91-99.

Pérez-Cabañero, C., González-Cruz, T. and Cruz-Ros, S. (2012), "Do family SME managers value marketing capabilities' contribution to firm performance?”, Marketing Intelligence \& Planning, Vol. 30 No. 2, pp. 116-142.

Prieto, I.M. and Revilla, E. (2006), "Learning capability and business performance: a non-financial and financial assessment”, The Learning Organization, Vol. 13 Issue 22, pp. 166 - 185.

Rakthin, S. Calantone, R.J. and Wang, J.F. (2016), "Managing market intelligence: The comparative role of absorptive capacity and market orientation", Journal of Business Research, Vol. 69 Issue 12, pp. 5569-5577.

Rivard, S. and Huff, S. L. (1988), "Factors of success for end-user computing”, Communications of the ACM, Vol. 31 Issue 5, pp. 552-561.

Siu, W.S. Fang, W. and Lin, T. (200), "Strategic marketing practices and the performance of Chinese small and medium-sized enterprises (SMEs) in Taiwan", Entrepreneurship \& Regional Development, Vol. 16 No. 2, pp. 161-78.

Slater, S.F. and Narver, J.C. (1994), "Does competitive environment moderate the market orientationperformance relationship?", The Journal of Marketing, Vol. 58 No. 1, pp. 46-55.

Sok, P., Snell, L., Lee, W.J., and Sok, K.M. (2017), "Linking entrepreneurial orientation and small service firm performance through marketing resources and marketing capability: A moderated mediation model", Journal of Service Theory and Practice, Vol. 27 No. 1, pp. 231-249.

Song, M., Benedetto, C.A.Di. and Nason, R.W. (2007), "Capabilities and financial performance: The moderating effect of strategic type", Journal of the Academy of Marketing Science, Vol. 35 No. 1, pp. 18-34.

Srockovic, M. (2017), "The performance effect of network and managerial capabilities of entrepreneurial firms", Small Business Economics, Vol. 50 Issue 4, pp 807-824

Srivastava, R., Reibstein, D.J. and Woodside, W.S. (2005), Metrics for Linking Marketing to Financial Performance, MA: Marketing Science Institute, Cambridge.

Takata, H. (2016), "Effects of industry forces, market orientation, and marketing capabilities on business performance: An empirical analysis of Japanese manufacturers from 2009 to 2011", Journal of Business Research, Vol. 69 Issue 12, pp. 5611-5619.

Tan, Q. and Sousa, C.M. (2015), "Leveraging marketing capabilities into competitive advantage and export performance”, International Marketing Review, Vol. 32 No. 1, pp. 78-102. 
Teece, D.J. (2017), "Business models and dynamic capabilities”, Long Range Planning, Vol. 51 Issue 1 , pp. 40-49

Varadarajan, R. (2012), "Marketing strategy: discerning the relative influence of product and firm characteristics", AMS Review, Vol. 1, pp. 32-43.

Vorhies, D. W., Morgan, R. E. and Autry, C. W. (2009), "Product-market strategy and the marketing capabilities of the firm: Impact on market effectiveness and cash flow performance", Strategic Management Journal, Vol. 30 Issue 12, pp. 1310-1334.

Wang, E.T., Hu, H.F. and Hu, P.J.H. (2013), "Examining the role of information technology in cultivating firms' dynamic marketing capabilities", Information \& Management, Vol. 50 Issue 6, pp. 336-343.

Woods, P., Gapp, R. and King, M.A. (2015), "Researching pharmacist managerial capability: philosophical perspectives and paradigms of inquiry" Research in Social and Administrative Pharmacy, Vol. 11 No. 2, pp. 265-279.

Zollo, M. Winter, S.G. (2002), "Deliberate learning and the evolution of dynamic capabilities", Organization Science, Vol. 13 No. 3, pp. 339-351.

The Role of Marketing Resources and Marketing

Dynamic Capabilities 